\title{
Effects of Grass Silage and Soybean Meal Supplementation on Milk Production and Milk Fatty Acid Profiles of Grazing Dairy Cows
}

\author{
O. A. Rego, ${ }^{\star 1}$ S. M. M. Regalo, ${ }^{*}$ H. J. D. Rosa, ${ }^{\star}$ S. P. Alves, †‡ A. E. S. Borba, ${ }^{\star}$ R. J. B. Bessa, $\dagger$ \\ A. R. J. Cabrita,§ and A. J. M. Fonsecał \\ *Centro de Investigação e Tecnologia Agrária dos Açores, Departamento de Ciências Agrárias, Universidade dos Açores, \\ 9701-851 Angra do Heroísmo, Portugal \\ †Rede de Química e Tecnologia (REQUIMTE), Unidade de Produção Animal, Instituto Nacional de Recursos Biológicos, Fonte Boa, \\ 2005-048 Vale de Santarém, Portugal \\ ‡REQUIMTE, Instituto de Ciências Biomédicas de Abel Salazar (ICBAS), and \\ §REQUIMTE, Secção Autónoma de Engenharia das Ciências Agrárias (SAECA), Faculdade de Ciências, Universidade do Porto, \\ Campus Agrário de Vairão, Rua Padre Armando Quintas, 4485-661 Vairão VC, Portugal
}

\begin{abstract}
The effects of supplementation with grass silage and replacement of some corn in the concentrate with soybean meal (SBM) on milk production, and milk fatty acid (FA) profiles were evaluated in a replicated $4 \times 4$ Latin square study using 16 dairy cows grazing pasture composed of ryegrass, Kentucky bluegrass, and white clover. Each experimental period lasted for $3 \mathrm{wk}$. The 4 dietary treatments were PC, $20 \mathrm{~h}$ of access to grazing pasture, supplemented with $6 \mathrm{~kg} / \mathrm{d}$ of corn-based concentrate mixture (96\% corn; C); PCSB, $20 \mathrm{~h}$ of access to grazing pasture, supplemented with $6 \mathrm{~kg} / \mathrm{d}$ of corn- and SBM-based concentrate mixture $(78 \%$ corn and $18 \%$ SBM; CSB); SC, $7 \mathrm{~h}$ of access to grazing pasture during the day and $13 \mathrm{~h}$ of ad libitum access to grass silage at night, supplemented with $6 \mathrm{~kg} / \mathrm{d}$ of $\mathrm{C}$ concentrate; and SCSB, $7 \mathrm{~h}$ of access to grazing pasture during the day and $13 \mathrm{~h}$ of ad libitum access to grass silage at night, supplemented with $6 \mathrm{~kg} / \mathrm{d}$ of CSB concentrate. The concentrate mixtures were offered twice each day in the milking parlor and were consumed completely. Grass silage supplementation reduced dietary crude protein and concentration of total sugars, and dietary SBM inclusion increased dietary crude protein concentration and decreased dietary starch concentration. Milk yield and energy-corrected milk were increased by SBM supplementation of cows with access to grass silage. Milk protein concentration was lower in cows offered grass silage, regardless of whether SBM was fed. Dietary SBM inclusion tended to increase milk fat concentration. Plasma urea $\mathrm{N}$ was reduced by silage feeding and increased by SBM supplementation. Supplementation with grass silage overnight could represent a useful
\end{abstract}

Received October 17, 2007.

Accepted March 31, 2008.

${ }^{1}$ Corresponding author: orego@uac.pt strategy for periods of lower pasture availability. Dietary inclusion of SBM in solely grazing cows had no effects on milk production and composition, exacerbated the inefficient capture of dietary $\mathrm{N}$, and increased diet cost. Grass silage supplementation affected milk FA profiles, increasing both the FA derived from de novo synthesis and those derived from rumen microbial biomass, and decreasing the sum of C18 FA (mostly derived from diet or from mobilization of adipose tissue reserves). Milk fat concentrations of conjugated linoleic acid cis-9, trans-11, vaccenic acid (18:1 trans-11), and linolenic acid (18:3n3 ) were unaffected by grass silage supplementation, suggesting that partial replacement of pasture by unwilted grass silage does not compromise the dietary quality of milk fat for humans.

Key words: dairy cow, grass silage and protein supplementation, grazing, milk fatty acid

\section{INTRODUCTION}

The Azorean archipelago, located in the Atlantic Ocean, is an important dairy region, being responsible for $27 \%$ of the total milk production of Portugal. In contrast to the dairy production systems of mainland Portugal, where cows are confined all year round and fed diets based on corn silage supplemented with high amounts of compound feeds, the climatic conditions of the Azores allow the grazing of animals throughout the year. This could be an advantage because intensive pasture-based systems could contribute to increased profitability and reduced feed costs (Clark and Kanneganti, 1998). However, the increase in the genetic potential of the animals in recent years has led to a higher utilization of compound feeds, because pasture does not meet the nutrient requirements for high-producing dairy cows (Kolver and Muller, 1998). Indeed, 2 factors that limit milk production on pasture are low DMI (Bargo et al., 2003) and a high content of highly degradable CP relatively to NSC 
(Carruthers et al., 1997; Mulligan et al., 2004). The low ruminal $\mathrm{N}$ capture contributes to both $\mathrm{N}$ pollution and to increased energetic expenditure for urea synthesis (Kolver and Muller, 1998). Therefore, one of the challenges of using pasture is maximizing ruminal $\mathrm{N}$ capture. This is often achieved by offering a compound feed consisting mainly of grain, with the type and processing method of grains having different effects (Reis and Combs, 2000; Wu et al., 2001; Mulligan et al., 2004).

The increase in the genetic potential of the animals in this region has also led to supplementation during the periods of lower pasture availability (winter) with conserved forages, mainly grass silage obtained from pasture in spring. The high level of $\mathrm{CP}$, particularly NPN, means that additional supplementation with true protein may be beneficial for stimulating rumen fermentation and for increasing AA absorption (Brito et al., 2007). This study was designed to evaluate the effects of grass silage supplementation and the replacement of part of the corn in a concentrate with soybean meal (SBM) on the productive response of grazing dairy cows during winter. Additionally, it is well known that grazing dairy cows produce milk with a more favorable fatty acid (FA) profile for human health-with increased concentrations of rumenic acid [18:2 cis-9, trans-11, hereafter termed conjugated linoleic acid (CLA) cis-9, trans-11], vaccenic acid (18:1 trans-11), and linolenic acid (18:3n3) - than milk from confined cows fed diets based on conserved forages (Dewhurst et al., 2006). Moreover, milk FA profiles have recently been used in assessing rumen function (Cabrita et al., 2003; Vlaeminck et al., 2006).

\section{MATERIALS AND METHODS}

\section{Pasture}

The feeding trial was conducted at the Dairy Unit of the Department of Agriculture Sciences, University of Azores (Portugal), from January 5 to March 30, 2005, following the European Union animal welfare Directive Number 86/609/EEC. This unit has approximately 60 milking cows, with a mean 305-d lactation record in 2005 of 7,000 kg. Animals had access to a permanent pasture comprising approximately $76 \%$ ryegrass (Lolium perenne), $14 \%$ Kentucky bluegrass (Poa pratensis), $5 \%$ white clover (Trifolium repens), and 5\% weeds and dead matter. Cows grazed paddocks of 2 ha, divided by traditional stone walls, at a herbage allowance of $28 \mathrm{~kg}$ of DM/ cow per d. Pregrazing pasture mass (kg of DM/ha) was measured by cutting 6 quadrats $\left(0.25 \mathrm{~m}^{2}\right)$ to ground level at 3-d intervals. Target herbage masses varied between 2,600 and 2,900 kg of DM/ha. Strips were grazed for 1 $\mathrm{d}$, and were delimited by mobile electric fences. Drinking water was always available at pasture.

\section{Design, Diets, and Management}

Sixteen multiparous [parity number $3.5(\mathrm{SD}=1.0)$ ] Holstein cows averaging $547 \mathrm{~kg}$ of BW (SD = 51.0), 145 DIM (SD $=43.7)$, and $24 \mathrm{~kg}$ of milk/d $(\mathrm{SD}=4.6)$ were used. Cows were grouped according to milk production, parity, and DIM and randomly assigned to dietary treatment sequences in a changeover design (four $4 \times 4$ Latin squares). Each experimental period lasted for $3 \mathrm{wk}$. The 4 dietary treatments were $\mathbf{P C}, 20 \mathrm{~h}$ of access to grazing pasture, supplemented with $6 \mathrm{~kg} / \mathrm{d}$ of corn-based concentrate mixture (96\% corn; Table 1; C); PCSB, $20 \mathrm{~h}$ of access to grazing pasture, supplemented with $6 \mathrm{~kg} / \mathrm{d}$ of corn- and SBM-based concentrate mixture $(78 \%$ corn and 18\% SBM; Table 1; CSB); SC, $7 \mathrm{~h}$ of access to grazing pasture during the day and $13 \mathrm{~h}$ of ad libitum access to grass silage at night, supplemented with $6 \mathrm{~kg} / \mathrm{d}$ of C concentrate; and SCSB, $7 \mathrm{~h}$ of access to grazing pasture during the day, and $13 \mathrm{~h}$ of ad libitum access to grass silage at night, supplemented with $6 \mathrm{~kg} / \mathrm{d}$ of CSB concentrate. Grass silage was prepared, during late May, from regrowth pasture sections (target areas of pasture were fertilized with $120 \mathrm{~kg}$ of N/ha and closed for $7 \mathrm{wk}$ ). Grass silage was harvested directly with a precision-chop harvester (FX 40, New Holland, Carnaxide, Portugal) at a theoretical chop length of $20 \mathrm{~mm}$, and ensiled in a bunker silo with the use of a silage additive (Biomax; Lactobacillus plantarum and Pediococcus pentosaceus; Vetagri, Cantanhede, Portugal), applied at a rate of $2 \mathrm{~L} / \mathrm{t}$ of green forage. The silo was opened after 6 mo. The raw materials were ground through a hammer mill with a $4-\mathrm{mm}$ screen, and the concentrate mixtures were prepared in a single batch. The concentrate mixtures $(3 \mathrm{~kg})$ were offered twice each day in the milking parlor and were consumed completely. Cows supplemented with grass silage were housed at night (1800 h) and individually fed in a tie-stall barn, and had continuous access to water. Grass silage was offered for ad libitum intake, with fresh feed offered each night $(1800 \mathrm{~h})$. The troughs were cleaned out each morning and orts were collected and weighed throughout the experiment. Grass silage offered was adjusted each week to produce weighbacks of approximately $15 \%$ of amounts fed. Samples of pasture, grass silage, concentrates, and orts were sampled daily during the last $5 \mathrm{~d}$ of each period and, after oven DM determination $\left(65^{\circ} \mathrm{C}, 48 \mathrm{~h}\right)$, were composited by period. Total DMI was predicted according to NRC (2001) [equation [1-2] in NRC (2001); DMI $=(0.372 \times \mathrm{FCM}+0.0968$ $\left.\times \mathrm{BW}^{0.75}\right) \times\left(1-\mathrm{e}^{[-0.192 \times(\text { wk of lactation+3.67) })}\right]$, and the DMI of pasture was calculated by difference. Cows were milked twice daily at 0730 and $1530 \mathrm{~h}$.

Milk production was measured throughout the experimental period. Milk was sampled at both milkings on 2 consecutive days during the last week of each experimen- 
REGO ET AL.

Table 1. Chemical analysis and fatty acid composition of experimental feeds

\begin{tabular}{|c|c|c|c|c|}
\hline \multirow[b]{2}{*}{ Item } & \multicolumn{2}{|c|}{ Forage } & \multicolumn{2}{|c|}{ Concentrate mixture } \\
\hline & Pasture & Grass silage & Corn $^{1}$ & Corn + soybean meal ${ }^{2}$ \\
\hline $\mathrm{DM}, \%$ & 17.0 & 22.8 & 88.8 & 89.0 \\
\hline $\mathrm{pH}$ & $\mathrm{ND}^{3}$ & 4.3 & ND & ND \\
\hline $\mathrm{NH}_{3}-\mathrm{N}, \%$ of $\mathrm{N}$ & ND & 5.9 & ND & ND \\
\hline Ash & 8.3 & 9.8 & 7.1 & 7.0 \\
\hline $\mathrm{CP}$ & 22.8 & 17.5 & 8.3 & 15.5 \\
\hline NDF & 49.8 & 53.4 & 9.8 & 10.0 \\
\hline $\mathrm{ADF}$ & 21.8 & 28.0 & 3.2 & 4.7 \\
\hline Acid detergent lignin & 1.6 & 2.5 & 1.4 & 2.2 \\
\hline Sugars & 7.0 & 0.9 & 2.0 & 3.0 \\
\hline Starch & ND & ND & 60.5 & 48.6 \\
\hline $\mathrm{P}$ & 0.4 & 0.4 & 0.7 & 0.8 \\
\hline Total fatty acids & 2.31 & 2.16 & 3.17 & 2.96 \\
\hline In vitro DM digestibility & 78.2 & 69.8 & ND & ND \\
\hline Fatty acid & 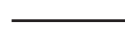 & - $(\mathrm{g} / 100$ & tal fatty & ) \\
\hline $14: 0$ & 1.0 & 1.2 & 0.3 & 0.2 \\
\hline $16: 0$ & 20.3 & 20.8 & 24.7 & 24.8 \\
\hline $16: 1$ cis -9 & 3.1 & 1.7 & 0.2 & 0.3 \\
\hline $18: 0$ & 2.8 & 2.3 & 2.6 & 2.7 \\
\hline $18: 1$ cis -9 & 3.3 & 3.4 & 27.9 & 26.9 \\
\hline $18: 2 n-6$ & 13.7 & 16.7 & 41.8 & 42.7 \\
\hline $18: 3 n-3$ & 55.8 & 53.8 & 2.3 & 2.4 \\
\hline
\end{tabular}

${ }^{1} 96 \%$ corn grain, $0.5 \%$ salt, and 3.5\% mineral premix (Minervet 2/1, Vetagri Alimentar SA, Cantanhede, Portugal).

${ }^{2} 78 \%$ corn grain, $18 \%$ soybean meal, $0.5 \%$ salt, and $3.5 \%$ mineral and vitamin premix (Minervet $2 / 1$, Vetagri Alimentar SA).

${ }^{3}$ Not determined.

tal period, and proportional composites were analyzed for fat and protein. Milk fat was isolated from individual milk samples, collected on the last day of milk sampling, by centrifugation for $15 \mathrm{~min}$ at $822 \times g$ and immediately stored at $-15^{\circ} \mathrm{C}$ until FA analysis. On the same day, blood samples were collected into heparinized tubes from the jugular vein of each cow after the a.m. milking. Samples were immediately centrifuged at $822 \times g$ for $10 \mathrm{~min}$, and the plasma was stored at $-15^{\circ} \mathrm{C}$ before analysis for BUN. Cows were weighed at the same time of the day (following the a.m. milking) on the 2 final days of each experimental period.

Duodenal flow of purine bases $(\mathbf{P B})$ was predicted from milk secretion of odd- and branched-chain FA as described by Vlaeminck et al. (2005) [equation [5] in Vlaeminck et al. (2005); duodenal flow of PB $(\mathrm{g} / \mathrm{d})=1.10 \times$ milk secretion of odd- and branched-chain FA (g/d)]. The milk secretion of odd- and branched-chain FA (g/d) was calculated as milk fat $(\mathrm{kg} / \mathrm{d}) \times 0.933 \times \mathrm{FA}(\mathrm{g} / 100 \mathrm{~g}) \times 10$.

\section{Chemical Analysis}

Samples of feeds from the last week of each experimental period were submitted for chemical analysis. The $\mathrm{pH}$ and the $\mathrm{NH}_{3}-\mathrm{N}$ concentration of grass silage were determined, in fresh samples, with a pH electrode (no.
209811250, Ingold, Mettler-Toledo Inc., Columbus, OH) and according to Conway (1957), respectively. Ground samples $(1 \mathrm{~mm})$ were analyzed for ash (AOAC, 1990; method 942.05) and Kjeldahl N (AOAC, 1990; method 954.01). Crude protein was calculated as Kjeldahl $\mathrm{N} \times$ 6.25. Neutral detergent fiber, $\mathrm{ADF}$, and acid detergent lignin were determined by the detergent procedures of Van Soest et al. (1991) and Robertson and Van Soest (1981), with $\alpha$-amylase being added for concentrates during NDF extraction; sodium sulfite was not added. Neutral detergent fiber was expressed without residual ash. Total sugars were determined by an official Portuguese standard method (Norma Portuguesa 1785, 1986) based on the Luff-Schoorl methodology, after extracting sugars with an ethanol solution. Phosphorous was determined by the gravimetric procedure described by the official Portuguese standard method (Norma Portuguesa 873, 1997). Starch was analyzed on finely ground samples (0.5-mm screen) by using the method described by Salomonsson et al. (1984). In vitro DM digestibility of grass silage and pasture was analyzed by the 2 -stage method of Tilley and Terry (1963). Milk fat and protein were determined by automated infrared analysis with a MilkoScan 605 instrument (Foss Electric, Hillerød, Denmark; AOAC, 1990). Jugular plasma was analyzed for urea N (AUG40 Automated Chemistry Analyzer, Olym- 
pus, Melville, NY) by an enzymatic (urease) method as described by Bauer (1982).

Fatty acid methyl esters of feed lipids were prepared by a one-step extraction transesterification procedure using toluene, according to Sukhija and Palmquist (1988). The internal standard was heptadecanoic acid. For milk FA analysis, $200 \mathrm{mg}$ of the milk fat layer was weighed into culture tubes, and milk lipids were extracted according to the procedure of Folch et al. (1957). Solvents were then evaporated under N, and FA methyl esters were prepared by base-catalyzed transesterification with sodium methoxide (Christie, 2004). Fatty acid methyl esters were analyzed with an HP6890 gas chromatograph (Agilent Technologies Inc., Palo Alto, CA), equipped with a flame-ionization detector, and a fusedsilica capillary column $($ CP-Sil $88,100 \mathrm{~m} \times 0.25 \mathrm{~mm} \times$ $0.20 \mu \mathrm{m}$, Chrompack CP 7489, Varian Inc., Walnut Creek, CA). The carrier gas was helium, and the split ratio was $1: 50$. The injector temperature was $250^{\circ} \mathrm{C}$, and the detector temperature was $280^{\circ} \mathrm{C}$. The initial oven temperature of $100^{\circ} \mathrm{C}$ was held for $15 \mathrm{~min}$, then increased at $10^{\circ} \mathrm{C} / \mathrm{min}$ to $150^{\circ} \mathrm{C}$, where it was held for 5 min, then increased at $1^{\circ} \mathrm{C} / \mathrm{min}$ to $158^{\circ} \mathrm{C}$ and held for $30 \mathrm{~min}$, and then increased at $1^{\circ} \mathrm{C} / \mathrm{min}$ to $200^{\circ} \mathrm{C}$ and held for $40 \mathrm{~min}$. Peak identification was based on cochromatography with known standards of FA methyl esters (Sigma, St. Louis, MO) and, when no commercial standards were available, by using published chromatograms obtained with similar analytical conditions (CruzHernandez et al., 2004; Alves et al., 2006).

\section{Statistical Analysis}

Data from the last week of each experimental period and FA profiles of milk samples were analyzed as replicated $4 \times 4$ Latin squares by using the MIXED procedure of SAS (SAS Institute Inc., Cary, NC). The model included the fixed effects of square, period, grass silage supplementation, type of concentrate, and the interaction of grass silage supplementation $\times$ type of concentrate, the random effect of cow within square, and the random residual error. Differences among treatments were considered to be significant when $P<0.05$, whereas when $P>0.05$ but $<0.10$, differences were considered to indicate a trend toward a significant effect.

\section{RESULTS AND DISCUSSION}

The chemical and FA compositions of the pasture, grass silage, and concentrate mixtures are given in Table 1. Pasture was relatively high quality, averaging (DM basis) $22.8 \% \mathrm{CP}, 49.8 \% \mathrm{NDF}, 7.0 \%$ total sugars, and $78.2 \%$ in vitro $\mathrm{DM}$ digestibility. Grass silage $\mathrm{pH}$ and $\mathrm{NH}_{3}-\mathrm{N}$ were, respectively, 4.3 and $5.9 \%$ of total $\mathrm{N}$, sug-
Table 2. Estimated nutrient composition of total diets ${ }^{1,2}$

\begin{tabular}{lrrrr}
\hline Item & \multicolumn{1}{c}{ PC } & PCSB & SC & SCSB \\
\cline { 2 - 5 } & \multicolumn{4}{c}{$(\% \mathrm{DM})$} \\
\cline { 2 - 5 } Ash & 8.0 & 8.0 & 8.6 & 8.5 \\
CP & 19.0 & 20.9 & 16.9 & 18.9 \\
EE & 1.6 & 1.5 & 2.1 & 1.9 \\
NDF & 39.2 & 39.3 & 40.6 & 40.9 \\
ADF & 16.9 & 17.3 & 19.3 & 19.8 \\
Acid detergent lignin & 1.5 & 1.8 & 1.9 & 2.1 \\
Sugars & 5.7 & 5.9 & 3.3 & 3.6 \\
Starch & 16.0 & 12.9 & 16.1 & 12.5 \\
P & 0.5 & 0.5 & 0.5 & 0.5 \\
Cost, ${ }^{3} \%$ & 100.0 & 109.6 & 116.8 & 124.2 \\
\hline
\end{tabular}

${ }^{1} \mathrm{PC}=20 \mathrm{~h}$ of access to grazing pasture, supplemented with $6 \mathrm{~kg} /$ $\mathrm{d}$ of corn-based concentrate mixture $(\mathrm{C}) ; \mathrm{PCSB}=20 \mathrm{~h}$ of access to grazing pasture, supplemented with $6 \mathrm{~kg} / \mathrm{d}$ of corn- and soybean mealbased concentrate mixture (CSB); $\mathrm{SC}=7 \mathrm{~h}$ of access to grazing pasture during the day and $13 \mathrm{~h}$ of ad libitum access to grass silage at night, supplemented with $6 \mathrm{~kg} / \mathrm{d}$ of C concentrate; SCSB $=7 \mathrm{~h}$ of access to grazing pasture during the day and $13 \mathrm{~h}$ of ad libitum access to grass silage at night, supplemented with $6 \mathrm{~kg} / \mathrm{d}$ of CSB concentrate.

${ }^{2}$ Estimated by using the average chemical composition of pasture and supplements, and weighing them according to estimated DMI (Table 3).

${ }^{3}$ Calculated in relation to the cost of the PC diet (according to feed costs in the Azores in February 2008).

gesting that silage was well preserved. The concentrations (DM basis) of CP (17.5\%) and NDF (53.4\%) as well as the in vitro DM digestibility (69.8\%) of the grass silage also suggested that it was of relatively high nutritive value. The chemical composition of the concentrate mixtures agreed closely with the ingredient composition. The corn-based concentrate contained (DM basis) $8.3 \%$ $\mathrm{CP}$ and $60.5 \%$ starch, and the CSB concentrate contained 15.5\% CP and $48.6 \%$ starch. Pasture and grass silage were both good sources of linoleic acid (18:2n-6; 13.7 and $16.7 \%$ of total FA, respectively) and linolenic acid (18:3n$3 ; 55.8$ and $53.8 \%$ of total FA, respectively). Concentrate FA compositions were very similar. The most representative FA were oleic acid (18:1 cis-9) and 18:2n-6, agreeing with the FA composition of corn grain. Estimated nutrient composition of the total diets (Table 2) showed that grass silage supplementation reduced dietary $\mathrm{CP}$ and total sugar concentrations. Dietary SBM inclusion increased dietary CP concentration and decreased dietary starch concentration.

\section{Feed Intake}

The estimation of intake by grazing cows is more complicated than that of confined cows. Despite the availability of several methods based on pasture and animal characteristics to estimate pasture intake (e.g., sward-cutting technique, estimation of diet digestibility, and fecal production using markers such as chromium oxide and alkanes; Bargo et al., 2003), in the present study, pasture 
Table 3. Least squares means for DMI, milk production, milk composition, BUN, predicted duodenal flow of purine bases (PB), and BW from the different dietary treatments ${ }^{1}$

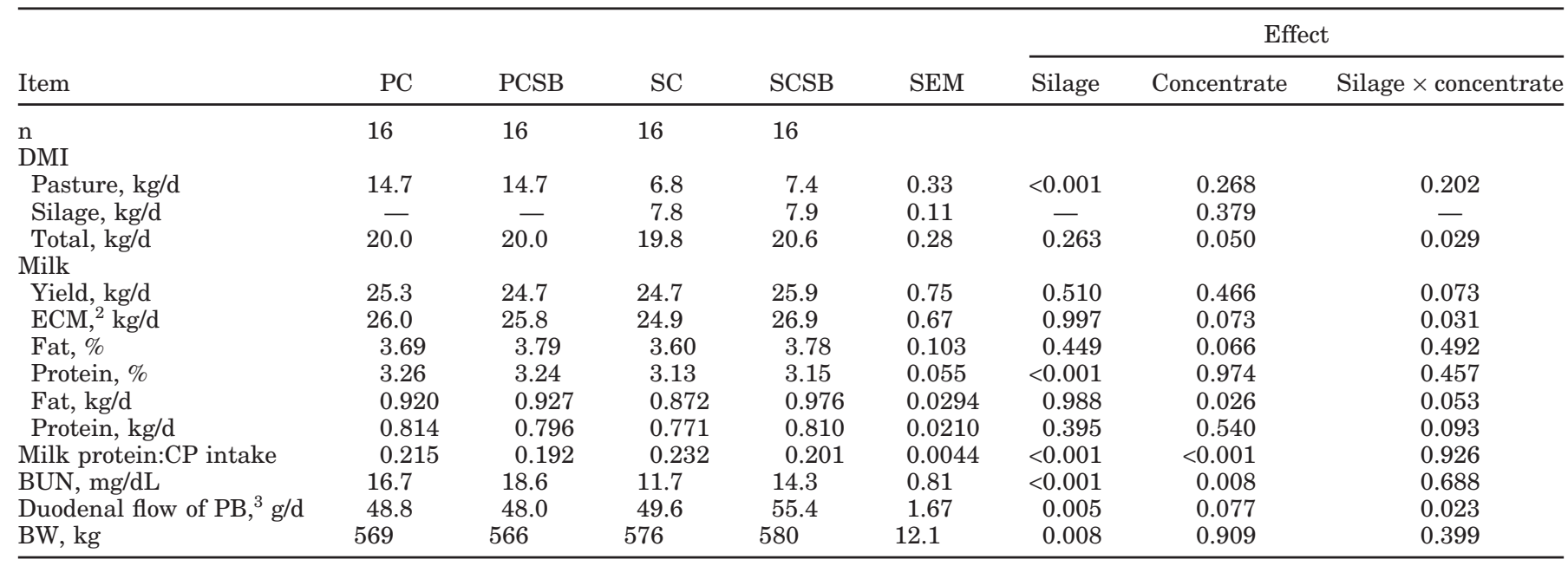

${ }^{1} \mathrm{PC}=20 \mathrm{~h}$ of access to grazing pasture, supplemented with $6 \mathrm{~kg} / \mathrm{d}$ of corn-based concentrate mixture $(\mathrm{C}) ; \mathrm{PCSB}=20 \mathrm{~h}$ of access to grazing pasture, supplemented with $6 \mathrm{~kg} / \mathrm{d}$ of corn- and soybean meal-based concentrate mixture (CSB); SC $=7 \mathrm{~h}$ of access to grazing pasture during the day and $13 \mathrm{~h}$ of ad libitum access to grass silage at night, supplemented with $6 \mathrm{~kg} / \mathrm{d}$ of $\mathrm{C}$ concentrate; $\mathrm{SCSB}=7 \mathrm{~h}$ of access to grazing pasture during the day and $13 \mathrm{~h}$ of ad libitum access to grass silage at night, supplemented with $6 \mathrm{~kg} / \mathrm{d}$ of CSB concentrate.

${ }^{2}$ Calculated as $(0.324 \times \mathrm{kg}$ of milk $)+(12.95 \times \mathrm{kg}$ of milk fat $)+(7.20 \times \mathrm{kg}$ of milk protein $)$.

${ }^{3}$ Predicted from milk secretion of odd- and branched-chain fatty acids as described by Vlaeminck et al. (2005) \{equation [5] in Vlaeminck et al. (2005); duodenal flow of PB $(\mathrm{g} / \mathrm{d})=1.10 \times$ milk secretion of odd- and branched-chain fatty acids $[\mathrm{g} / \mathrm{d}$; calculated as milk fat $(\mathrm{kg} / \mathrm{d}) \times$ $0.933 \times$ fatty acids $(\mathrm{g} / 100 \mathrm{~g}) \times 10]\}$.

intake was estimated by difference using the equation proposed by NRC (equation [1-2] in NRC, 2001). Bargo et al. (2003) compared the estimation of DMI obtained by the use of several equations with that obtained by the use of chromium oxide as a fecal marker and concluded that the NRC (2001) equation was accurate and had the advantage of being simpler and of requiring only animal factors (FCM, BW, and week of lactation). As in the present study, similarly to the above-mentioned study (Bargo et al., 2003), cows were in midlactation, producing approximately $25 \mathrm{~kg}$ of milk/d and supplemented with $6 \mathrm{~kg} / \mathrm{d}$ of $\mathrm{C}$, the DMI estimation was expected to be reliable.

Effects on feed intake are presented in Table 3. Grass silage supplementation did not affect total DMI, with the silage $\times$ concentrate interaction suggesting that dietary SBM inclusion promoted higher DMI when cows were also supplemented with grass silage. However, caution should be used when interpreting these results because of the limitations in the way total DMI was estimated: cows on treatment SCSB produced more milk (and ECM; Table 3), which would lead to a greater estimate of total DMI. The greater milk production observed with treatment SCSB could be due to a greater DMI, to a greater efficiency of nutrient use for milk synthesis, or both.

\section{Milk Production and Milk Composition}

Effects on milk production, milk composition, BW, $\mathrm{BUN}$, and predicted duodenal flow of $\mathrm{PB}$ are presented in Table 3. Milk yield and ECM were not affected by silage supplementation. However, replacing part of the corn grain (18\%) in the concentrate by SBM (true protein) tended to increase milk yield $(P=0.073)$ and increased ECM in cows with access to silage, whereas there was no effect in cows that were solely grazing. The positive effects could reflect an improvement in ruminal fermentation. Indeed, because the ensiling process increases NPN content, replacing part of the corn with a true protein source (SBM) will eventually benefit microbial growth through supplying preformed AA (Brito et al., 2007), as well as through the effects on rumen $\mathrm{pH}$ (lower dietary starch concentration). Indeed, predicted duodenal flow of PB increased with dietary SBM inclusion, suggesting a higher rumen microbial activity. However, this was not reflected in higher milk protein content, and increased the cost of supplement (Table 2).

Grass silage supplementation decreased milk protein concentration, although milk protein production was not affected. Milk protein content of grazing dairy cows tends to be reduced by dietary grass silage inclusion, particularly when cows have ad libitum access to pasture (Phillips, 1988). This could arise from either the reduction in total energy intake or the low $\mathrm{N}$ retention of grass silage compared with fresh herbage. Phillips and Leaver (1985) found that milk protein content tended to be reduced even when total energy intake was increased by grass silage supplementation. The effect of dietary SBM inclusion on milk protein production of cows having access 
to grass silage reflects the higher milk production. Milk fat concentration $(P=0.066)$ and production were increased by dietary SBM inclusion. These results agree with the lower starch content of treatments PCSB and SCSB (Table 2). It is well known that postruminal glucose and ruminal propionic acid preferentially channel nutrients to adipose tissue, resulting in a shortage of nutrients at the mammary gland and thus milk fat depression (glucogenic-insulin theory; Brockman and Laarveld, 1986). Silage supplementation led to an improvement in the BW of cows, as in previous studies (Crosse and Gleeson, 1987; O’Brien et al., 1996).

The conversion of dietary $\mathrm{N}$ into milk $\mathrm{N}$ was lower in solely grazing cows than in grass silage-supplemented cows, and this efficiency was decreased by dietary SBM inclusion (Table 3). Indeed, grass silage supplementation decreased BUN, and the dietary SBM inclusion increased BUN. These results agree with dietary CP concentration and suggest an inefficient capture of pasture $\mathrm{N}$ that is even greater with SBM supplementation. Therefore, the present study does not support the use of SBM in pasture diets because of the higher energy expenditure for excretion of $\mathrm{N}$ as well as for the higher cost of the diet (Table 2).

\section{Milk FA}

The dietary effects on milk FA profiles are given in Table 4. Grass silage supplementation had only a minor, but significant, effect on milk FA, whereas the type of concentrate did not affect them. Allowing ad libitum access to grass silage during the night increased 10:0, 11:0, 12:0, 14:0, iso-15:0, anteiso-15:0, and 15:0, and decreased iso-17:0, 18:0, 18:1 cis-9, and 18:2n-6. Thus, silage supplementation increased the FA derived from de novo synthesis (sum of short and medium even-chained saturated FA; 8:0 to 14:0) from 16.3 to 17.6 (\% of total $\mathrm{FA}$ ), and the FA derived from rumen microbial biomass (sum of odd- and branched-chain FA) from 5.8 to 6.2 (\% of total FA). Moreover, grass silage supplementation decreased the sum of C18 FA, mostly derived from diet or from mobilization of adipose tissue reserves from 46.8 to 44.1 ( $\%$ of total FA). Because body fat mobilization is not expected to be of great importance in cows averaging 145 DIM, the reduction of C18 FA could be explained by a lower intake of these FA. The content of total lipids of silages is generally lower than that of the original grass (Dewhurst and King, 1998). Moreover, ensiling leads to an extensive lipolysis of forage lipids, and thus to a substantial increase in NEFA (Vanhatalo et al., 2007). Nevertheless, in the present trial the differences in FA concentration between pasture and silage were small and the estimated FA intake $(499 \pm 6.39 \mathrm{~g} / \mathrm{d})$ was not affected by treatments. Additionally, the increase in microbial FA could reflect an improvement in rumen fermentation, and hence higher availability of VFA for de novo synthesis of FA, which could dilute the C18 FA.

Milk PUFA concentration averaged $4.2 \%$ of total FA, and it was unaffected by treatments. Together, 18:2n- 6 and 18:3n-3 constituted $41 \%$ of milk PUFA, and this proportion was also unaffected by treatments, in spite of the significant, but small, effect observed on 18:2n-6. Overall, these minor effects could be justified by the small differences between the FA composition of pasture and grass silage used (Table 1). Fatty acid composition of milk produced by grazing cows has consistently higher content of unsaturated FA, particularly of CLA cis-9, trans-11, 18:1 trans-11, and 18:3n-3. Hence, it is considered to be healthier than milk from confined cows fed diets based on conserved forages (Dewhurst et al., 2006). In the present experiment, the milk FA profile is consistent with milk from pasture-fed cows (Dewhurst et al., 2006; Elgersma et al., 2006), and the inclusion of silage did not change it. Additionally, the concentration of CLA cis-9, trans-11 was high (1.44\% of total FA) and was highly correlated with 18:1 trans- $11(\mathrm{r}=0.87, \mathrm{n}=64)$, as reported by others (Jahreis et al., 1997; Chilliard et al., 2003). Elgersma et al. (2006) reviewed the concentration of CLA cis-9, trans-11 in milk fat; the level of CLA cis-9, trans-11 reported here was similar to milk from grazing cows in Ireland and New Zealand and was surpassed only by milk from cows grazing in the Alpine highlands. The large variation observed in CLA cis-9, trans-11 and 18:1 trans-11 concentrations in milk fat of individual cows $(0.28$ to $4.11 \%$ and 0.71 to $6.96 \%$ of total FA, respectively) has been observed in other studies (Kelly et al., 1998; Rego et al., 2004) and has been attributed to individual differences in the activity of $\Delta^{9}$-desaturase in animal tissues (Salter et al., 2007).

\section{CONCLUSIONS}

Although supplementation with grass silage overnight led to reduced milk protein concentration, there was no effect on the milk production of grazing dairy cows, so it could represent a useful strategy for periods of lower pasture availability. Dietary inclusion of SBM was beneficial in cows supplemented with silage. Its inclusion in solely grazing cows had no effect on milk production and composition, exacerbated the inefficient capture of dietary $\mathrm{N}$, and increased diet cost. Milk FA profiles were consistent with milk from pasture-fed cows in earlier work, with the concentration of CLA cis-9, trans-11 being high. Grass silage supplementation increased the FA derived from de novo synthesis and the FA derived from rumen microbial biomass, and decreased the sum of $\mathrm{C} 18$ FA, mostly derived from diet or from mobilization of adipose tissue reserves. Milk CLA cis-9, trans-11, vac- 
Table 4. Least squares means for milk fatty acids ( $\mathrm{g} / 100 \mathrm{~g}$ of total fatty acids) from the different dietary treatments ${ }^{1}$

\begin{tabular}{|c|c|c|c|c|c|c|c|c|}
\hline \multirow[b]{2}{*}{ Fatty acid } & \multirow[b]{2}{*}{$\mathrm{PC}$} & \multirow[b]{2}{*}{ PCSB } & \multirow[b]{2}{*}{$\mathrm{SC}$} & \multirow[b]{2}{*}{ SCSB } & \multirow[b]{2}{*}{ SEM } & \multicolumn{3}{|c|}{ Effect } \\
\hline & & & & & & Silage & Concentrate & Silage $\times$ concentrate \\
\hline 8:0 & 0.44 & 0.31 & 0.33 & 0.39 & 0.049 & 0.707 & 0.447 & 0.051 \\
\hline $10: 0$ & 2.20 & 2.04 & 2.30 & 2.31 & 0.109 & 0.025 & 0.356 & 0.310 \\
\hline $11: 0$ & 0.25 & 0.23 & 0.27 & 0.27 & 0.016 & $<0.001$ & 0.240 & 0.253 \\
\hline $12: 0$ & 3.00 & 2.95 & 3.40 & 3.23 & 0.126 & $<0.001$ & 0.182 & 0.459 \\
\hline iso-14:0 & 0.12 & 0.11 & 0.11 & 0.11 & 0.006 & 0.612 & 0.823 & 0.342 \\
\hline $14: 0$ & 10.86 & 10.79 & 11.86 & 11.43 & 0.275 & $<0.001$ & 0.236 & 0.406 \\
\hline iso-15:0 & 0.70 & 0.67 & 0.73 & 0.76 & 0.026 & 0.026 & 0.995 & 0.278 \\
\hline anteiso-15:0 & 1.02 & 1.01 & 1.20 & 1.13 & 0.085 & 0.003 & 0.394 & 0.563 \\
\hline $15: 0$ & 1.19 & 1.14 & 1.38 & 1.37 & 0.033 & $<0.001$ & 0.364 & 0.490 \\
\hline iso-16:0 & 0.30 & 0.29 & 0.28 & 0.28 & 0.013 & 0.219 & 0.999 & 0.683 \\
\hline $16: 0$ & 26.02 & 26.93 & 27.77 & 27.10 & 0.973 & 0.298 & 0.901 & 0.390 \\
\hline $16: 1$ trans -9 & 0.15 & 0.16 & 0.13 & 0.13 & 0.017 & 0.175 & 0.848 & 0.801 \\
\hline iso-17:0 & 0.74 & 0.72 & 0.68 & 0.70 & 0.018 & 0.016 & 0.985 & 0.226 \\
\hline 16:1 cis-9 & 1.28 & 1.34 & 1.37 & 1.36 & 0.076 & 0.350 & 0.759 & 0.541 \\
\hline anteiso-17:0 & 0.54 & 0.51 & 0.54 & 0.55 & 0.014 & 0.153 & 0.646 & 0.106 \\
\hline $17: 0$ & 0.61 & 0.60 & 0.60 & 0.62 & 0.014 & 0.498 & 0.548 & 0.258 \\
\hline iso-18:0 & 0.03 & 0.02 & 0.02 & 0.02 & 0.003 & 0.759 & 0.689 & 0.814 \\
\hline $17: 1 \mathrm{cis}-8$ & 0.10 & 0.10 & 0.11 & 0.10 & 0.003 & 0.430 & 0.504 & 0.859 \\
\hline $17: 1$ cis -9 & 0.30 & 0.31 & 0.29 & 0.32 & 0.015 & 0.643 & 0.186 & 0.414 \\
\hline $18: 0$ & 12.90 & 13.18 & 11.88 & 12.19 & 0.489 & 0.016 & 0.461 & 0.970 \\
\hline $18: 1$ trans -6 to -8 & 0.27 & 0.26 & 0.27 & 0.24 & 0.020 & 0.400 & 0.416 & 0.665 \\
\hline $18: 1$ trans -9 & 0.21 & 0.22 & 0.21 & 0.19 & 0.014 & 0.433 & 0.742 & 0.415 \\
\hline 18:1 trans -10 & 0.39 & 0.34 & 0.44 & 0.30 & 0.063 & 0.947 & 0.142 & 0.496 \\
\hline 18:1 trans -11 & 3.06 & 3.19 & 2.86 & 3.05 & 0.356 & 0.639 & 0.651 & 0.933 \\
\hline $18: 1 c i s-9$ & 23.91 & 23.60 & 21.30 & 22.76 & 0.686 & $<0.001$ & 0.196 & 0.049 \\
\hline 18:1 cis -11 & 1.09 & 1.05 & 1.08 & 1.06 & 0.057 & 0.976 & 0.518 & 0.843 \\
\hline $18: 1$ cis -12 & 0.23 & 0.21 & 0.22 & 0.21 & 0.012 & 0.692 & 0.254 & 0.894 \\
\hline 18:1 cis-13 & 0.10 & 0.11 & 0.13 & 0.11 & 0.012 & 0.189 & 0.753 & 0.349 \\
\hline 18:1 trans -16 & 0.60 & 0.56 & 0.66 & 0.59 & 0.048 & 0.328 & 0.257 & 0.802 \\
\hline 18:1 cis-15 & 0.22 & 0.19 & 0.26 & 0.23 & 0.024 & 0.160 & 0.238 & 0.939 \\
\hline $18: 2$ other isomers ${ }^{2}$ & 0.49 & 0.44 & 0.61 & 0.48 & 0.054 & 0.139 & 0.123 & 0.461 \\
\hline 18:2 trans -11 , cis -15 & 0.30 & 0.29 & 0.30 & 0.26 & 0.027 & 0.653 & 0.264 & 0.579 \\
\hline $18: 2 n-6$ & 1.05 & 1.08 & 0.99 & 0.98 & 0.034 & 0.006 & 0.779 & 0.559 \\
\hline $20: 0$ & 0.17 & 0.18 & 0.17 & 0.16 & 0.008 & 0.129 & 0.901 & 0.709 \\
\hline 18:3n-3 ～～～～～ & 0.63 & 0.61 & 0.67 & 0.63 & 0.028 & 0.203 & 0.149 & 0.741 \\
\hline CLA cis -9, trans -11 & 1.43 & 1.37 & 1.47 & 1.49 & 0.180 & 0.673 & 0.899 & 0.830 \\
\hline $22: 0$ & 0.06 & 0.06 & 0.06 & 0.06 & 0.003 & 0.677 & 0.932 & 0.206 \\
\hline $20: 3 n-6$ & 0.07 & 0.07 & 0.07 & 0.07 & 0.003 & 0.603 & 0.988 & 0.976 \\
\hline $20: 4 n-6$ & 0.09 & 0.09 & 0.09 & 0.09 & 0.004 & 0.760 & 0.556 & 0.820 \\
\hline $20: 5 n-3$ & 0.09 & 0.09 & 0.09 & 0.08 & 0.005 & 0.867 & 0.617 & 0.357 \\
\hline $22: 5 n-3$ & 0.05 & 0.05 & 0.05 & 0.05 & 0.003 & 0.655 & 0.265 & 0.534 \\
\hline Unidentified & 2.65 & 2.46 & 2.69 & 2.43 & 0.144 & 0.941 & 0.117 & 0.821 \\
\hline
\end{tabular}

${ }^{1} \mathrm{PC}=20 \mathrm{~h}$ of access to grazing pasture, supplemented with $6 \mathrm{~kg} / \mathrm{d}$ of corn-based concentrate mixture $(\mathrm{C})$; $\mathrm{PCSB}=20 \mathrm{~h}$ of access to grazing pasture, supplemented with $6 \mathrm{~kg} / \mathrm{d}$ of corn- and soybean meal-based concentrate mixture (CSB); $\mathrm{SC}=7 \mathrm{~h}$ of access to grazing pasture during the day and $13 \mathrm{~h}$ of ad libitum access to grass silage at night, supplemented with $6 \mathrm{~kg} / \mathrm{d}$ of C concentrate; SCSB $=7 \mathrm{~h}$ of access to grazing pasture during the day and $13 \mathrm{~h}$ of ad libitum access to grass silage at night, supplemented with $6 \mathrm{~kg} / \mathrm{d}$ of CSB concentrate.

${ }^{2} 18: 2$ other isomers $=$ sum of 18:2 isomers eluting after 18:1 cis-15 and 18:2 trans-11, cis-15.

cenic acid (18:1 trans-11), and linolenic acid (18:3n-3) concentrations were unaffected, suggesting that partial replacement of pasture by unwilted grass silage does not compromise the dietary quality of milk fat for humans.

\section{ACKNOWLEDGMENTS}

This work was partially financed by the Luso-American Development Foundation (FLAD; Lisbon, Portugal), which is gratefully acknowledged.

\section{REFERENCES}

Alves, S. P., C. Marcelino, P. V. Portugal, and R. J. B. Bessa. 2006. Short communication: The nature of heptadecenoic acid in ruminant fats. J. Dairy Sci. 89:170-173.

AOAC. 1990. Official Methods of Analysis. Vol. I. 15th ed. AOAC, Arlington, VA.

Bargo, F., L. D. Muller, E. S. Volver, and J. E. Delahoy. 2003. Production and digestion of supplemented dairy cows on pasture. J. Dairy Sci. 86:1-42.

Bauer, J. D. 1982. Clinical Laboratory Methods. 9th ed. D. Ladig, ed. The C.V. Mosby Co., St. Louis, MO. 
Brito, A. F., G. A. Broderick, and S. M. Reynal. 2007. Effects of different protein supplements on omasal nutrient flow and microbial protein synthesis in lactating dairy cows. J. Dairy Sci. 90:1828-1841.

Brockman, R. P., and B. Laarveld. 1986. Hormonal regulation of metabolism in ruminants: A review. Livest. Prod. Sci. 14:313-334.

Cabrita, A. R. J., A. J. M. Fonseca, R. J. Dewhurst, and E. Gomes. 2003. Nitrogen supplementation of corn silages. 2. Assessing rumen function using FA profiles of bovine milk. J. Dairy Sci. 86:4020-4032.

Carruthers, V. R., P. G. Neil, and D. E. Dalley. 1997. Effect of altering the non-structural:structural carbohydrate ratio in a pasture diet on milk production and ruminal metabolites in cows in early and late lactation. Anim. Sci. 64:393-402.

Chilliard, Y., A. Ferlay, J. Rouel, and G. Lamberet. 2003. A review of nutritional and physiological factors affecting goat milk lipid synthesis and lipolysis. J. Dairy Sci. 86:1751-1770.

Christie, W. W. 2004. Lipid Analysis. 3rd ed. The Oily Press, PJ Barnes \& Associates, Bridgwater, UK

Clark, D. A., and V. R. Kanneganti. 1998. Grazing management system for dairy cattle. Page 331 in Grass for Dairy Cattle. J. H. Cherney, and D. J. R. Cherney, ed. CAB Int., Oxon, UK.

Conway, E. J. 1957. Microdiffusion Analysis and Volumetric Error. Crosby, Lockwood and Son Ltd., London, UK.

Crosse, S., and P. Gleeson. 1987. Supplementation of autumn grass with silage and concentrates for grazing dairy cows in late lactation. Ir. J. Agric. Res. 26:69-75.

Cruz-Hernandez, C., Z. Deng, J. Zhou, A. R. Hill, M. P. Yurawecz, P. Delmonte, M. M. Mossoba, M. E. R. Dugan, and J. K. G. Kramer. 2004. Methods for analysis of conjugated linoleic acid and trans18:1 isomers in dairy fats by using a combination of gas chromatography, silver-ion thin-layer chromatography/gas chromatography, and silver-ion liquid chromatography. J. AOAC Int. 87:545-562.

Dewhurst, R. J., and P. J. King. 1998. Effects of extended wilting, shading and chemical additives on the fatty acids in laboratory grass silages. Grass Forage Sci. 53:219-224.

Dewhurst, R. J., K. J. Shingfield, M. R. F. Lee, and N. D. Scollan 2006. Increasing the concentrations of beneficial polyunsaturated fatty acids in milk produced by dairy cows in high-forage systems. Anim. Feed Sci. Technol. 131:168-206.

Elgersma, A., S. Tamminga, and G. Ellen. 2006. Modifying milk composition through forage. Anim. Feed Sci. Technol. 131:207-225.

Folch, J., M. Less, and G. H. Stanley Sloane. 1957. A simple method for the isolation and purification of total lipids from animal tissues. J. Biol. Chem. 226:497-509.

Jahreis, G., J. Fritsche, and H. Steinhart. 1997. Conjugated linoleic acid in milk fat: High variation depending on production system. Nutr. Res. 17:1479-1484.

Kelly, M. L., E. S. Kolver, D. E. Bauman, M. E. Van Amburgh, and L. D. Muller. 1998. Effect of intake of pasture on concentrations of conjugated linoleic acid in milk of lactating dairy cows. J. Dairy Sci. 81:1630-1636.

Kolver, E. S., and L. D. Muller. 1998. Performance and nutrient intake of high producing Holstein cows consuming pasture or a total mixed ration. J. Dairy Sci. 81:1403-1411.

Mulligan, F. J., P. Dillon, J. J. Callan, M. Rath, and F. P. O’Mara. 2004. Supplementary concentrate type affects nitrogen excretion of grazing dairy cows. J. Dairy Sci. 87:3451-3460.
NRC. 2001. Nutrient Requirements of Dairy Cattle. 7th ed. Natl. Acad. Press, Washington, DC.

Norma Portuguesa 1785. 1986. Determinação do teor de açúcares. Diário da República, III Série de 30/05, no. 123. Lisbon, Portugal.

Norma Portuguesa 873. 1997. Alimentos para animais, determinação do teor de fósforo, método gravimétrico. Lisbon, Portugal.

O'Brien, B., S. Crosse, and P. Dillon. 1996. Effects of offering a concentrate or silage supplement to grazing dairy cows in late lactation on animal performance and on milk processability. Ir. J. Agric. Res. 35:113-125.

Phillips, C. J. C. 1988. The use of conserved forage as a supplement for grazing dairy cows. Grass Forage Sci. 43:215-230.

Phillips, C. J. C., and J. D. Leaver. 1985. Supplementary feeding of forage to grazing dairy cows. 2. Offering grass silage in early and late season. Grass Forage Sci. 40:193-199.

Rego, O. A., P. V. Portugal, M. B. Sousa, H. J. D. Rosa, C. M. Vouzela, A. E. S. Borbaa, and R. J. B. Bessa. 2004. Effect of diet on the fatty acid pattern of milk from dairy cows. Anim. Res. 53:213-220.

Reis, R. B., and D. K. Combs. 2000. Effects of corn processing and supplemental hay on rumen environment and lactation performance of dairy cows grazing grass-legume pasture. J. Dairy Sci. 83:2529-2538.

Robertson, J. B., and P. J. Van Soest. 1981. The Detergent System of Analysis and Its Application in Human Foods. W. P. T. James and O. Theander, ed. Marcel Dekker Inc., New York, NY.

Salomonsson, A., A. Theander, and E. Westerlund. 1984. Chemical characterization of some Swedish cereal whole meal and bran fractions. Swed. J. Agric. Res. 14:111-117.

Salter, A. M., A. L. Lock, P. C. Garnsworthy, and D. E. Bauman. 2007. Milk fatty acids: Implications for human health. Pages 1-18 in Recent Advances in Animal Nutrition. P. C. Garnsworthy and J. Wiseman, ed. Nottingham Univ. Press, Nottingham, UK.

Sukhija, P. S., and D. L. Palmquist. 1988. Rapid method for determination of total fatty-acid content and composition of feedstuffs and feces. J. Agric. Food Chem. 36:1202-1206.

Tilley, J. M. A., and R. A. Terry. 1963. A two stage technique for in vitro digestion of forage crops. J. Br. Grassl. Soc. 18:104-111.

Van Soest, P. J., J. B. Robertson, and B. A. Lewis. 1991. Symposium: Carbohydrate methodology, metabolism, and nutritional implications in dairy cattle. Methods for dietary fiber, neutral detergent fiber, and nonstarch polysaccharides in relation to animal nutrition. J. Dairy Sci. 74:3583-3597.

Vanhatalo, A., K. Kuoppala, V. Toivonen, and K. J. Shingfield. 2007. Effects of forage species and stage of maturity on bovine fatty acid composition. Eur. J. Lipid Sci. Technol. 109:856-867.

Vlaeminck, B., C. Dufour, A. M. van Vuuren, A. R. J. Cabrita, R. J. Dewhurst, D. Demeyer, and V. Fievez. 2005. Use of odd- and branched-chain fatty acids in rumen contents and milk as a potential microbial marker. J. Dairy Sci. 88:1031-1042.

Vlaeminck, B., V. Fievez, A. R. J. Cabrita, A. J. M. Fonseca, and R. J. Dewhurst. 2006. Factors affecting odd- and branched-chain fatty acids in milk: A review. Anim. Feed Sci. Technol. 131:389-417.

Wu, Z., L. J. Massingli, R. P. Walgenbach, and L. D. Satter. 2001. Cracked dry or finely ground high moisture shelled corn as a supplement for grazing cows. J. Dairy Sci. 84:2227-2230. 